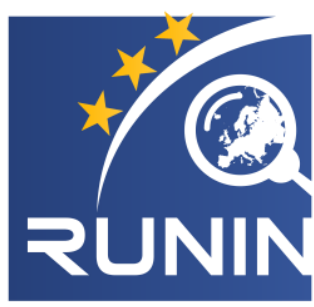

The Role of Universities in Innovation and Regional Development

\title{
The unlversity third mission and the European Structural Funds In peripheral reglons Insights from Finland
}

WORKING PAPER 07/2019

DOI: $10.3990 / 4.2535-5686.2019 .07$

Available at https://runinproject.eu/results/working-paper-series/

\section{Marla Salomaa}

University of Lincoln (UK)

\msalomaa@lincoln.ac.uk

\section{David Charles}

Northumbria University (UK)

\david.charles@northumbria.ac.uk 


\section{Abstract}

Current EU policies prioritise supporting national and regional R\&D activities and innovation systems. In particular, Cohesion Policy transformed into national Structural Funds (SF) Operational Programmes aim to foster local level innovation. At the same time, the discussion on universities' 'third mission' has expanded and the role of universities has become crucial both in regional innovation strategy formulation and implementation of these strategies, which partly guide the access to local SF funding. However, binding the third mission to interaction with regional industry and fostering regional entrepreneurship and economic growth is not uncomplicated. This is also the case with university-led SF projects, though they can enable matching research better with local priorities. Through a case study of the University Consortium of Pori, a multi-disciplinary higher education network located in a peripheral region of Satakunta in Western Finland, this paper investigates how entrepreneurial universities can manage and deliver their third mission through Structural Funds programmes in a rural region. The tentative findings reveal individual researchers' strong commitment to regional engagement, but the implementation of SF projects remains challenging for Finnish universities because of institutional issues, higher education policies focusing on traditional academic outputs and the strict guidelines of SF funding. Only strategically planned university-led SF projects can generate synergies between teaching, research and engagement activities, which is not easily achieved without a strong engagement of the university management. As the SF programmes are heavily dependent on the regional context, further comparative studies on university-led SF projects could provide more insights on the ways the third mission activities can be delivered and managed more efficiently.

Keywords: Structural Funds, entrepreneurial university, third mission, regional development, University Consortia

JEL: R58; I23; O31 


\section{Contents}

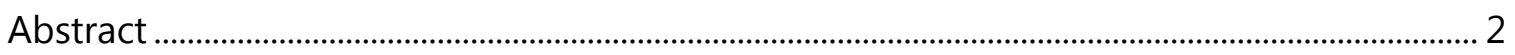

1. Introduction .............................................................................................................................

2. Universities, third mission and Structural Fund programmes ..........................................

2.1. Towards entrepreneurial universities.........................................................................

2.2. Universities and Structural Fund programmes ....................................................... 9

2.3. Universities engagement with Structural Funds: current challenges..............11

3. Methods and case study .............................................................................................................

3.1. Methodology ……………………………………………………………………………...

3.2. The case study overview......................................................................................................

4. Structural Funds at the University Consortium of Pori..........................................................18

4.1. Collaboration …………………………………………………………………...2

4.2. SF administrative procedures .................................................................................2

4.3. University organisation culture ............................................................................2

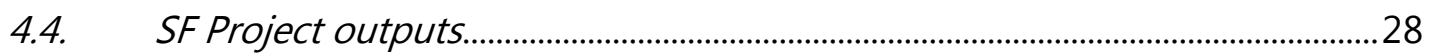

5. Discussion: Academic core and SF activities .........................................................................29

5.1. Characteristics of university-led SF projects........................................................30

5.2. Managing of regional engagement activities in entrepreneurial universities

6. Conclusion: Academic core and regional development - Managing universities' third mission through Structural Funds programmes ...........................................................................37

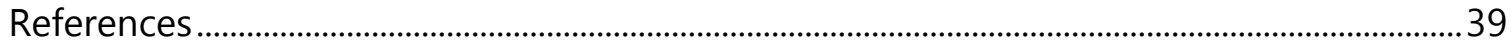

\section{Tables}

Table 1. Challenges of university-led SF projects.

Table 2. The impact of current challenges in university-led SF projects in the case of UCPori. 


\section{Introduction}

Current EU policies place an increasingly important role in supporting national and regional $R \& D$ activities and innovation systems (European Commission, 2010). One of the EU's key instruments, Cohesion Policy implemented through national Structural Funds (SF) Operational Programmes, aims to support local level innovation to reduce economic and social disparities (EU 1301/2013). This is currently implemented through the smart specialisation concept, which drives more place-based EU policies (McCann \& Ortega-Argilés, 2015). The role of universities has become crucial both in regional innovation strategy formulation, especially in RIS3 ${ }^{1}$ processes identifying the regional priorities (e.g. Foray et al., 2009), but also in implementation of the strategies (Santos \& Caseiro, 2015). These strategies guide the access to local European Regional Development Fund (ERDF) and European Social Fund (ESF) programmes, which can facilitate matching universities' research more closely with regional needs (Fonseca \& Salomaa, 2019).

Universities are increasingly recognised as important actors in regional development (Charles et al., 2014) and a 'third mission' focused on engagement and external services has been acknowledged as an addition to the traditional core functions of teaching and research (Chatterton \& Goddard, 2000; Jongbloed et al., 2008). Policymakers expect universities to facilitate entrepreneurship and technology transfer, binding the third mission to interaction with regional industry and society (Arbo \& Benneworth, 2007; Roper \& Hirth, 2005; Zomer \& Benneworth, 2012), but this role of fostering regional entrepreneurship and economic growth may be challenging for universities (Gibb \& Hannon, 2006). Overall, the discussion

\footnotetext{
${ }^{1}$ Research and Innovation Strategy for Smart Specialisation.
} 
has been widely dominated by the concept of the 'entrepreneurial university' (Clark, 1998; 2004; Vorley \& Nelles 2009), which is strongly linked with universities' enhanced engagement role. The entrepreneurial university has been described as an organisation that embeds economic and social development more closely into research, education and technology transfer activities so that all three academic missions support one another (Etzkowitz \& Kloften, 2005; Etzkowitz, 2013). In practise, the volume of expected entrepreneurial spillovers from academia has not been realistic in recent policy frameworks, even more so in peripheral regions with a limited innovation capacity. In such regions, it has been suggested that the focus of innovation policies should be on supporting the absorptive capacity of local SMEs and promoting networking and knowledge exchange (Brown, 2016), which resonates well with ERDF funding priorities for the programme period 2014-2020².

However, universities seeking to become entrepreneurial should acknowledge that their regional contexts steer the way they can implement third stream activities (Salomaa, 2019), and identify how the third mission can be delivered on a micro scale instead of using the concept merely in 'promotional terms' (Lebeau \& Cochrane, 2015). SF programmes can support universities to deliver engagement activities, especially in less-developed regions: previous case studies show that they have contributed to creating the foundations of regional systems of innovation as well as having reinforced universities' regional engagement (Charles \& Michie, 2013). Universities are also among the key beneficiaries of these funds (e.g. Spilanis et al., 2016). In Finland, so far universities are the lead beneficiaries of 519 ESF and ERDF projects with ca. 140M EUR of granted SF funding in programme

\footnotetext{
${ }^{2}$ https://ec.europa.eu/regional_policy/en/policy/how/priorities/, $1^{\text {st }}$ Aug 2019.
} 
period 2014-2020. ${ }^{3}$ Taking part or leading Structural Funds projects may be a concrete way to engage with regional development and initiate entrepreneurial activities beyond spinoffs and other research spillovers.

In Finland, the enhanced regional role of universities is emphasised in higher education policies: the third mission has become more closely linked with regional development, which has resulted in the establishment of university consortia to foster the economic growth in locations lacking universities, and to coordinate and improve universities' collaboration building on local strengths (MoEC ${ }^{4}, 2015$; FINHEEC, ${ }^{5}$ 2013). Since 2004, six university consortia have been established in more peripheral areas of Finland. In other countries, peripheral university campuses struggle to respond to the expectations of regional partners compared with the experiences of full-range universities (Charles, 2016), but the unique organisational structure of the Finnish university consortia, which combines different disciplines and the expertise of several home universities, may overcome this issue.

Through a case study of the University Consortium of Pori (UC-Pori), a multidisciplinary higher education network of four Finnish universities, this paper investigates how entrepreneurial universities can manage and deliver their third mission through Structural Funds programmes by examining the specific characteristics of university-led SF activities. A qualitative analysis of the UC-Pori's engagement with SF programmes identifies how universities can respond to regional needs while linking the projects to teaching and research, and how the management of these activities could be enhanced. First, the entrepreneurial

\footnotetext{
${ }^{3}$ Structural Funds Information Service, https://www.eura2014.fi/rrtiepa/index.php?lang=en, $2^{\text {nd }}$ Aug 2019.

${ }^{4}$ The Ministry of Education and Culture.

5 The Finnish Higher Education Evaluation Council.
} 
university literature is reviewed in relation to how universities engage with SF, particularly paying attention to the current challenges. Then the case of UC-Pori is introduced and their use of SF funding analysed in order to identify how these activities are or are not aligned with the core missions. Finally, based on the key findings from UC-Pori, the characteristics of university-led SF projects are identified and the overall management of third mission activities further discussed.

\section{Universitles, third mission and Structural Fund programmes}

\subsection{Towards entrepreneurial universities}

The development of the concept of the entrepreneurial university (Clark, 1998) emerged in parallel with policymakers' increasingly high expectations of universities' contributions to regional development (Arbo \& Benneworth, 2007; Breznitz \& Feldman, 2012). University organisations have become portrayed as highly flexible, integrated and strategic actors (Uyarra, 2010), though in reality, universities can respond to the regional needs only up to a certain level, especially when operating in a traditional academic infrastructure (Clark, 1998). Whilst policymakers' expectations for universities to meet regional needs and embed a range of new tasks to their core missions may be unrealistic (Uyarra, 2010), the universities' 'third' engagement role has grown to be widely acknowledged and formalised particularly in regional policies and R\&D funding incentives (Vorley \& Nelles, 2009; Nelles \& Vorley, 2010). As a result, universities have become more connected to regional partners through various engagement mechanisms (Uyarra, 2010), but also via relationships with non-academic collaborators (Agrawal, 2001). 
Universities have embedded a regional focus more strongly in their missions (Charles et al., 2014), but it remains challenging to combine the third mission with the two other core functions in universities' internal mechanisms (Chatterton \& Goddard, 2000). This push towards third stream activities has broadened the scope of universities from teaching and research activities and made them 'organizational umbrellas' for different tasks from scholarship to entrepreneurial activities. (Stensaker \& Benner, 2013). Ideally, an "entrepreneurial university" is something that has a capability to embed both economic and social development into the core functions so that each academic mission enhances one another (Etzkowitz, 2013). All this emphasises the importance of institutional strategies addressing the different disciplinary, institutional and individual academics' characteristics (Pinheiro et al., 2015).

National policies have a major role in creating the context and conditions that enable universities to transform strategically towards entrepreneurial organisations (Stensaker \& Benner, 2013) and define the conditions of funding for universities' regional engagement activities (Trippl et al., 2015). However, universities should be cautious in their responses to regional needs; for example, a broadened curriculum and pragmatically developed research portfolio to match with local knowledge interests might steer organisational behaviour towards opportunism rather than intentionally entrepreneurial strategies (Stensaker \& Benner, 2013). In the Finnish $\mathrm{HE}$ policies, the third mission may include a number of different activities, which demand strategic planning and management, such as exploitation of research results outside of the academic community, contributing to innovation processes and establishing start-ups, graduates entering the job market, Open University education and providing complementary training, collaboration with local 
stakeholders, participation to public discussion, but also being part of a university consortium to deliver these activities in smaller towns (FINHEEC, 2013).

\subsection{Universities and Structural Fund programmes}

The European Structural Funds have evolved considerably from their origin as a form of resource transfer for economic infrastructure. Since the 1990s the dominance of the knowledge economy concept in EU policies, and an emphasis on supporting economic competitiveness though innovation and knowledge, has led to a general shift in EU programmes towards multi-sectoral and multi-disciplinary collaboration to address grand societal challenges that go beyond merely fostering economic growth (Benneworth \& Cunha, 2015). The SF have therefore become a key policy instrument to support local level innovation and economic growth through multi-level collaboration. They are implemented through Operational Programmes, which among other aims, seek to increase regional collaboration between higher education, businesses and other local stakeholders. ${ }^{6}$ Hence, the SF funding may also play a significant role in universities' transformation towards the entrepreneurial university. A diversified funding base increases institutional autonomy (Gibb \& Hannon, 2006; Armbruster, 2008), though monetary incentives alone are not sufficient for promoting university-industry collaboration ( $D^{\prime}$ Este \& Perkmann, 2011). Therefore, it is important to evaluate the outcomes and impact of university-led SF projects in-depth: do they contribute to core missions or are they considered as mere 'add-ons'? What kind of regional benefits can be generated?

\footnotetext{
${ }^{6}$ See Sustainable growth and jobs 2014 - 2020 - Finland's structural funds programme, https://www.rakennerahastot.fi/documents/10179/43217/Ohjelma-asiakirja+valmis.pdf/, accessed $30^{\text {th }}$ of August 2017.
} 
The Operational Programmes are nationally differentiated and very dependent on regional circumstances (Bachtler \& Wren, 2007), thus the existing studies of their operation and impact remain heavily rooted in specific territorial contexts. In general, SF activities have not been studied much from the beneficiaries' point of view, though also beneficiary objectives vary enormously; public actors receiving SF funds are more interested with projects having an immediate effect to demonstrate their efficiency whereas private entities use SF funding for financing start ups or enhancing their operational capacity (Spilanis et al., 2015). However, a few lessons can be learned from previous studies. In Latvia, SF projects have contributed to achieving core academic results, such as $\mathrm{PhD}$ degrees and publications (Muizniece \& Peiseniece, 2012), whereas a case study of North England reveals that SF programmes have brought together industry and university representatives, especially in university-based projects focused on engagement and building a culture of collaboration. A strong university sector in regions with little R\&D infrastructure can initiate industry-focused innovation support services with SF project funding, especially aimed at SMEs. (Charles \& Michie, 2013.)

The implementation of the SF projects demands both strategic and financial planning, but also knowledge of the national guidelines of the Operational Programmes. In Latvia, most of the university-led projects are non-commercial, because such projects can realise a higher funding rate compared to SF projects aimed at commercial activity (Muizniece \& Peiseniece, 2012). This is an interesting observation when thinking of the narrow gap between universities' entrepreneurial and opportunistic organisational behaviour (e.g. Stensaker \& Benner, 2013) - even if the participation in SF projects is considered to be an entrepreneurial activity, the choice to go for non-commercial projects may demonstrate a lack of 
organisational (financial) commitment or unwillingness to collaborate with nonacademic partners, both of which may hinder universities' contribution to regional R\&D activities.

\subsection{Universities engagement with Structural Funds: current challenges}

Previous studies have disclosed a number of challenges hindering universities from taking part in Structural Funds projects. These somewhat overlapping constraints are linked to the nature of the SF programmes themselves, the outcomes of the implemented projects, difficulties in establishing successful collaboration and internal issues related to university organisations. SF programmes operate through a partnership framework and often require some degree of collaboration to ensure university activities contribute to economic development. As regional programmes, funded projects are restricted to regional boundaries. This can make collaboration difficult where desired partners are in other regions and can even led to undesirable competition between regional actors (FINHEEC, 2013). As the Latvian case study reveals, it can also be difficult to engage with local businesses in the framework of SF projects (Muizniece \& Peiseniece, 2012), which is a general problem for universities based in more peripheral regions lacking other knowledge institutions and potential business partners (Charles, 2016).

Universities have also a number of internal barriers that hinders their participation in SF activities. On a very practical level, the timetable demands of teaching restrict the scale and timing of such 'extra' work (FINHEEC, 2013), but also the increasing pressure to prioritise institutional success over wider public benefits can create tensions (Benneworth \& Cunha, 2015): unless engagement activities are linked to a broader institutional change, these activities will remain peripheral (Benneworth and Sanderson, 2009). Therefore, SF projects can be considered as a distraction 
unless strongly aligned with teaching and research. In the case of Finnish university consortia, their regional role has become somewhat less emphasised because of their home universities' strategic focus steers the consortia towards traditional academic outputs (FINHEEC, 2013). This indicates that linking SF projects - or other engagement activities - strategically to universities' traditional core functions is not straightforward. Another challenge for Finnish universities is the state's core funding model (MoEC, 2017) that favours traditional academic outcomes (FINHEEC, 2013). This may reduce the motivation to carry out third stream activities even though universities' societal role has been formally acknowledged (e.g. Universities Act 558/2009). Thus, universities have funded their regional development activities with supplementary funds from the municipalities, regions and SF programmes (MoEC, 2015). In particular, the university consortia regard SF programmes as an important funding instrument for regional development (FINHEEC, 2013), though they cannot directly fund basic research.

The administrative burden of SF has made the programmes less appealing. According to evaluations of previous programme periods, some operational programmes have ended up suffering from low demand because of the bureaucracy (Bachtler \& Wishlade, 2004). Also, universities consider the SF funding instruments to be very bureaucratic and a high-risk form of funding (Spilanis et al., 2016; FINHEEC, 2013). The complexity of administration hinders using SF effectively to promote competitiveness and more innovative initiatives have been funded from national sources (Bachtler \& Wishlade, 2004). Despite the large number of evaluation activities, the overall impact of SF on sustainable economic growth and convergence of lagging regions remains questionable and difficult to assess (Percoco, 2017), which is partly due to these administrative constraints (Rodriguez- 
Pose \& Fratesi, 2003), but also due to an insufficient tailoring of the territorial approach for different areas (Gagliardi \& Percoco, 2017), e.g. rural regions. Also, a strong regional and organisational coordination is essential in ensuring that beneficiaries are not implementing identical or analogous SF activities (Muizniece \& Peiseniece, 2012). Participation in Structural Funds programmes diversifies universities funding base, but they are considered 'risky' as they require some percentage of the match funding from the beneficiaries themselves, and the payment of the grant is linked to a successful implementation of the project. Finnish universities have indeed had problems with the high match-funding rates, which again make the SF funding less attractive (FINHEEC, 2013).

Finally, there are challenges in terms of the kinds of outputs and outcomes needed from SF projects. There is a tendency for SF projects to set unrealistic goals for outputs, sometimes just to ensure funding, resulting in over-claimed number of firms assisted and jobs created (Charles \& Michie, 2013), though the outputs of university-led SF projects can vary enormously. In Latvia, the SF have been significant in developing the university's research capacity and contributed to R\&D activities in the absence of other available external funding streams, but obtaining commercial outcomes, such as licensed patents and commercialisation of research, have been less successful. (Muizniece \& Peiseniece, 2012.) However, SF projects have facilitated entrepreneurial engagement activities within universities (e.g. Charles \& Michie, 2013), which can be beneficial especially in peripheral regions. Such projects can also facilitate achieving regional policy objectives - in rural regions namely increasing the absorptive capacity of local SMEs and promoting networking and knowledge exchange (Brown, 2016.) 
These challenges are summarised in Table 1 in four groups, which form the basis of analysing the specific characteristics of university-led SF activities in the case of UC-Pori. The aim is to reveal how universities in rural regions can respond to local needs while linking the SF project activities to teaching and research.

Table 1. Challenges of university-led SF projects

\begin{tabular}{|l|l|}
\hline Challenge & Impact \\
\hline Collaboration & $\begin{array}{l}\text { Create non-desirable competition } \\
\text { Lack of regional coordination } \\
\text { Lack of business partners (peripheral regions) }\end{array}$ \\
\hline SF administrative procedures & $\begin{array}{l}\text { High bureaucracy } \\
\text { High risk form of funding } \\
\text { High match-funding rates } \\
\text { Difficulties in cross-regional collaboration }\end{array}$ \\
\hline SF Project outputs & $\begin{array}{l}\text { Embedding projects to academic core complicated } \\
\text { Lack of financial resources for match-funding } \\
\text { Lack of internal coordination } \\
\text { Lack of academic outputs }\end{array}$ \\
\hline & $\begin{array}{l}\text { Over-estimated outputs } \\
\text { Lack of academic outputs } \\
\text { Low number of commercial results }\end{array}$ \\
\hline
\end{tabular}

\section{Methods and case study}

\subsection{Methodology}

This is an exploratory study on how universities are able to manage and deliver their regional engagement activities through Structural Funds funded projects: the assumption being that SF programmes support implementation of universities' third mission. However, as discussed in the previous section, there are a number of challenges related to SF funding instruments, university organisations and national 
higher education policies that hinder participation and reaching maximum benefits of such activities. These issues are examined with a single case study of the University Consortium of Pori (UC-Pori), a Finnish university network consisting of four university organisations located in the Satakunta region. The case study of UC-Pori aims to highlight university consortia's engagement to SF programmes to receive further insights on how the current barriers can be overcome, given especial focus on how the SF projects can be embedded into universities core missions.

Despite the rigorous monitoring and evaluation of $\mathrm{SF}$, there is a need for further programme and project level studies to "gain more insight into the effectiveness of interventions and delivery mechanisms" (Bachtler \& Wren 2006, p. 151). Also, university participation in SF projects and its impact is yet largely underresearched. Instead of attempting to assess the 'total' impact of SF programmes, there has been a shift towards studying 'conditioning factors' that may explain the effectiveness of policies. Operational Programme level evaluations have more potential to contribute to national and subnational policy formulation processes (Fratesi \& Wishlade, 2017.)

A case study approach was chosen on the basis that it enables the examination of the phenomenon in more depth, and the case selection followed the logic of 'atypical cases' to obtain a richer data set to create a deeper understanding on the phenomenon (Flyvbjerg, 2006). In the Satakunta region more than $30 \%$ of the regionally allocated SF funds are granted to higher education (RCS, 2017), and at the time of the interviews, UC-Pori was involved with 19 SF projects generating up to 9.5 million EUR of external funding ${ }^{1}$. In addition to being actively engaged with SF funding, UC-Pori, as all the Finnish University consortia, has a special focus on 
regional development, and its unique organisational structure enables the inclusion of four Finnish case universities within a 'single' case study.

This paper presents tentative results from a data set that was gathered between December 2017 and December 2018. It draws from 25 interviews with UC-Pori units' and their home universities' personnel working with SF funded projects, including both academics and supporting staff members, and top management, namely rectorate, deans and research and enterprise personnel. The choice of interviewees was based on the public information on university beneficiaries of funded ERDF and ESF projects in the Satakunta region7: a request for a research interview was sent out to every PI and/or contact person of these projects. The database was checked regularly in order to obtain up-to-date information on funded projects to secure a comprehensive data set and further interviewees were detected through the snow-ball approach (e.g. Saunders et al., 2012). The interviews were recorded, transcribed and coded with NVivo 11 to ease categorising similar data chunks for further analysis, and finally drawing conclusions (Miles et al., 2014) on the characteristics of university-led SF projects.

\subsection{The case study overview}

Finnish university consortia are higher education collaboration networks that coordinate the education and research activities of several 'parent universities' in areas otherwise lacking access to university activities. Their position was legitimised in 2009, when they were added to the Finnish University Act (Universities Act 558/2009), and later in 2012, when additional regulations on their state funding

\footnotetext{
${ }^{7}$ Structural Fund information service: ERDF and ESF projects in Finland during the 2014-2020 programme period, https://www.eura2014.fi/rrtiepa/?lang=en, $1^{\text {st }}$ of Sept 2017.
} 
allocation were approved. The establishment of these consortia was justified by the enhanced societal role of higher education, and they were designed to respond to local needs. (FINHEEC, 2013.) Besides providing a local access to higher education and being a source of skilled workforce, these consortia are expected to play an enhanced role in regional development and they have been especially active in taking part in Structural Funds (SF) projects.

The University Consortium of Pori is a higher education network located in the Satakunta region on the southwest coast of Finland. The population of the region is $220,398^{8}$ and it has two regional centers, the cities of Pori and Rauma. The regional economy is based on energy production, engineering, offshore process industry, ports and logistics and the food industry. ${ }^{9}$ The Tampere University of Technology (TUT) has provided degree education in engineering in the area since the late 1980s, and today it is the coordinating university of the UC-Pori, established in its current form in 2003. The other universities, all working under the same roof in a historic factory building in the central Pori, are the University of Tampere (UTA $)^{10}$, University of Turku (UTU) and Aalto University (Aalto). Together these universities form an umbrella organisation for 2500 students and 170 staff members in the city of Pori, focusing on education and research activities mainly in arts and media (Aalto), engineering and technology (TUT), social sciences (UTA) and business and maritime studies (UTU). ${ }^{11}$ The personnel are directly recruited by their parent universities, but the staff members work permanently at the Pori

\footnotetext{
${ }^{8}$ https://www.tilastokeskus.fi/tup/suoluk/suoluk_vaesto_en.html\#demographicdependencyratiobymunicipali ty,2017, $20^{\text {th }}$ of Feb 2019.

${ }^{9}$ Regional Council of Satakunta website, http://www.satakuntaliitto.fi/english, $12^{\text {th }}$ Nov 2018.

${ }^{10}$ After a long planning process, TUT and UTA merged together with Tampere University of Applied

Sciences in the beginning of 2019 (https://www.tuni.fi/en/about-us, $20^{\text {th }}$ of Feb 2019).

${ }^{11}$ UCPori website, http://www.ucpori.fil, $12^{\text {th }}$ Nov 2018.
} 
campus in their respective units. The coordinating unit nominates a director and is also responsible for promoting collaboration between UC-Pori units, parent universities and regional stakeholders.

The Regional Council of Satakunta (RCS) regards local higher education as one of the strategic factors that increases the region's general attractiveness and contributes to knowledge capital (Satakunta Regional Programme 2014-2017). According to their report, UC-Pori has raised the local skills level as well as increased the inflow and rate of R\&D activities (RCS, 2017). From a historic perspective, the SF have been important in establishing regional university branch units in the Satakunta region. In the early 2000, the SF funding was indeed a central element in developing research capacity in the area and supporting the presence of higher education in the region. Especially bringing in new disciplines to the Pori campus to increase the local knowledge base demanded supplementary funding, but since then the importance of SF - as well as the amount of available funding has decreased, which is mostly due to the renewed University Act and the shift towards more performance-based state funding indicators. However, all units of the UC-Pori participate actively in SF programmes, though TUT and UTU were granted more projects than Aalto and UTA, both of which have smaller and very specialised units in the Pori campus.

\section{Structural Funds at the University Consortium of Porl}

UC-Pori units typically collaborate with local businesses, public organisations especially in healthcare sector, and the city of Pori. Many SF projects result from long-term collaboration with these regional actors. The majority of the UC-Pori 
personnel have been working with SF projects for a long period of time, and it is very common to apply for extensions to projects. The interviewees described very different agendas, individual motivations and benefits from SF projects, but their role was acknowledged as particularly important in setting up the UC-Pori units: "In the very beginning of the millennium, the SF funding was central in developing research capacity in the area" (TUT, researcher).

In general, SF programmes were seen as an important source of funding for universities, especially for such remote branch campuses that have a stronger regional mission. At the same time, many respondents also recognized that their home universities remain more focused on funding instruments that directly contribute to teaching and research activities, which makes SF funding less appealing and overlooked in strategic planning. Some of the interviewees described SF projects as "a catalyst of change" (UTU, researcher), that enable finding new ways to work, also regarding basic missions, e.g. developing online teaching platforms.

The somewhat differing orientation of UC-Pori's home universities towards high profile research projects was seen as quite contrary to these more regionally focused units located in the Pori campus. Especially for the HEIs located in the capital area of Finland "the whole concept of SF is unknown" (Aalto, researcher). In the following sections, these issues are presented highlighting the challenges of university-led SF projects (see Table 1) at UC-Pori and finally discussed further in the relation to entrepreneurial university literature. 


\section{The university third mission and the European Structural Funds in peripheral regions \\ Insights from Finland}

\subsection{Collaboration}

One of the most repeated advantages of SF projects was that they encourage collaboration with other higher education institutions and businesses, which facilitates knowledge transfer and capacity building. The projects were seen as " $a$ natural way for us to approach businesses" (TUT, researcher) and collaboration was described to be meaningful for both academics themselves and the region of Satakunta:

"I find it interesting to combine business collaboration with more applied approach and academic research." (UTU, researcher).

"--you feel that you can do something good for the partners" (UTU, researcher).

The regional policies were considered to be one of the key factors affecting UCPori's motivation to engage with SF funding. There is an increased demand from the Satakunta region towards UC-Pori, but also the personnel in the Pori campus deliberately seek ways to engage with local stakeholders through SF programmes. The UC-Pori's knowledge base is considered as an advantage in the RIS $3^{12}$ strategy and it was represented in the design process of the regional strategic plan ${ }^{13}$ through series of future workshops. Some units were also involved in setting success indicators for regional goals. Curiously, the management of the parent universities did not recognize how these regional programmes are built or how UC-Pori is actually involved with these processes. Generally, the top management

\footnotetext{
${ }^{12} \mathrm{http} / / /$ www.satakuntaliitto.fi/sites/satakuntaliitto.fi/files/RIS3 Satakunta2014_TEM.pdf 1st of Jan 2019. ${ }^{13}$ http://www.satakuntaliitto.fi/sites/satakuntaliitto.fi/files/tiedostot/Aluekehitys/MAKO_2018 2021/Sataku nnan_maakuntaohjelma_2018-2021_SahkoinenJulkaisu_LowRes.pdf 1st of Jan 2019.
} 
of the parent universities are not very active in regional networks, and they only visit the Pori campus once a year or even less frequently.

In contrast, the local researchers brought up the importance of following the regional strategic plan "it defines the key areas, so we have to do our homework before starting to build new ideas and project consortia" (TUT, researcher). It was seen as rather easy to find common angles, because the both the RIS3 strategy and the SF calls' themes echo UC-Pori's central disciplines, especially in the circular economy, wellbeing technology and automation and robotics. However, it can be challenging to find suitable business partners from the region. Although UC-Pori aims to fill these local skills gaps stated in the strategies, the parent universities criticised the UC-Pori's curricula for not being developed as a response to local needs but rather based on individual academics' interests to work in the Satakunta region. Even if all the SF activities are not aligned with regional priorities, UC-Pori has been able to bring in much needed knowledge and initiate SF projects e.g. in health sector and robotics (e.g. KAMPUS-SOTE ${ }^{14}$ and AutoRobo ${ }^{15}$ ).

Most projects are multidisciplinary in nature; big changes in the business environment require multidisciplinary responses. The proximity of different universities of UC-Pori increases internal collaboration, also with parent universities. The UC-Pori units are highly specialised, so it might be challenging to find common interfaces, though it was also considered as an advance:

\footnotetext{
${ }^{14}$ Campusbased competence building for social welfare and healthcare services, https://sites.tuni.fi/kampussote/in-english/ $2^{\text {nd }}$ of Aug 2019.

${ }_{15}$ Autonomous Robot Ecosystem, https://www.tuni.fi/en/research/autonomous-robot-ecosystem, $2^{\text {nd }}$ of Aug 2019.
} 


\section{The university third mission and the European Structural Funds in peripheral regions \\ Insights from Finland}

"There is an added value in having four universities together -- it is easy to step out of your own scientific field and establish projects with researchers from different fields, which enables examining the research problem from different aspects and finding new solutions." (UC-Pori, management).

The regional RIS3 strategy highlights local HEIs, UC-Pori in particular, as key players in supporting regional growth, but the focus is largely on technology transfer and supporting entrepreneurship, thus different units of the UC-Pori are in an unequal position when applying for SF funding. These disciplinary issues are evident also when examining the funded SF projects. Social science and arts and culture are marginal compared with technology and business projects: "It is so easy for us to create concrete applications and programmes -- maybe it is more difficult for humanities" (TUT, researcher).

In the absence of a tradition of cooperation between academics and other stakeholders in the Satakunta region, the SF project activities have contributed to creating a culture of collaboration: "In the beginning they were suspicious and thought that we are in some ivory tower" (UTU, researcher). SF projects allow researchers to work "in the field" (Aalto, researcher), get in touch and discuss with different actors. The interviewees also thought that regional engagement through SF projects may have an impact on local authorities and policymaking: "this is what I hope from the SF projects: to increase the regional impact and mission" (UTU, researcher).

Some of the interviewees agreed that responding to regional needs should be prioritised in all UC-Pori's activities: the UC-Pori is supported by the city of Pori, so "we should bring something back" (TUT, researcher), also the Regional Council of Satakunta expects universities to participate in SF projects, though the researchers 
struggle to justify these engagement activities as "the main campus does not necessarily know what we are doing here" (TUT, researcher). The same concern was raised also in regard to funding authorities, which are currently more scattered across Finland. Currently, the SF projects are managed by many funding authorities located in different regions, namely government bodies and most importantly, four Finnish Centres for Economic Development, Transport and the Environment (ELY Centres) having a specific task to coordinate SF programmes. The interviewees thought that this might affect to the allocation of SF funds as the funding authorities located in different regions lack the local knowledge. Therefore, the bidding processes were not always considered to be transparent or fair. In addition, some of the interviewees thought that there is not enough regional coordination for creating synergies or optimising the benefits from on-going SF projects.

\subsection{SF administrative procedures}

One of the appeals of SF funding is the high success rate of proposals in comparison to applications to other funding instruments. However, despite the recent national efforts to simplify the administration work, many of the researchers struggled with the bureaucracy, especially in ESF projects. The funding authorities do not provide consistent guidelines on eligibility criteria, which causes extra work, or in the worst case, clawbacks. There were big differences also in the support offered by the UC-Pori units' parent universities, some of which had rather straightforwardly signalled, that SF projects are an unwanted form of external funding. Even though the city of Pori has provided generous support for SF projects' match-funding, which is typically very complicated to generate from external sources, universities' internal administration mechanism, the so called 'full cost model' is more compatible with other research funding (e.g. Academy of 
Finland, Business Finland). However, the interviewees stated that "--we have learned how to use SF instruments here in Porl' (Aalto, researcher).

In some cases, research group's bidding success rate was as high as $100 \%$ and there is a strong tradition of carrying out SF projects at the UC-Pori: "we have always got a lot of money from SF funding" (TUT, researcher). This raised concerns about rooting the research too much on the local needs at the expense of academic excellence: "-- many of our research groups are used to getting a lot of ERDF funding, so they do not see need to go for the other research funding. They have used to getting funding too easily." (UC-Pori, management). SF funding was considered to be very accessible mainly because of regional factors, which can also have a negative impact:

"-the competition (in SF) is not so tough because of its regional limitations. In the long term, it can lead to the dominance of SF projects, which makes their role distorted and decreases research ambition as people will finally mix it up with research funding instruments." (UC-Pori, management).

Sometimes SF projects were applied for just to safeguard jobs. This was more often the case for project researchers, typically PhD students working on their research projects 'on the side', and for other staff members, such as personnel working on continuing education services. The latter typically had permanent contracts however, they were also expected to "get funding from somewhere" (TUT, staff).

Although some of the SF projects have generated new content for continuous education, e.g. in maritime studies, or even piloted degree study programmes, the current SF guidelines no longer allow such activities: "ERDF funding has diminished and become more business-oriented, which makes it complicated at the moment" 
(UTU, researcher). Therefore, the current development projects have remained less beneficial for the degree study programmes: "I hope these could be more linked. There is a possibility to run a course on robotics (based on SF activities) and there are few publications from the project." (TUT, researcher).

All these aspects combined may threaten the quality of SF projects: "some of the SF projects are applied just for the sake of getting external funds, so the projects themselves are not always so excellent" (UTU, researcher). Particularly the researchers working full-time in these projects thought that a further decrease of SF funds in the coming programme period is not just a threat for single employees, but to the whole regional engagement activities of university units in the Pori campus.

\subsection{University organisation culture}

The project initiatives came typically from single researchers or research groups without coordination or intervention of UC-Pori or their parent university. Only one of the HEIs present in UC-Pori described that its parent university has tightened the monitoring on a project level due to ongoing large scale organisational changes, but the others could still work somewhat independently, though they needed a formal authorisation for bids from their universities: "When we win a project, the university do not care very much, someone just takes care of it" (TUT, researcher). The researchers are typically very enthusiastic to plan and initiate cooperation with many stakeholders, but without strategic planning the activities tend to end together with the external funds. On the other hand, the personnel of UC-Pori widely suggested that the researchers currently work 'as entrepreneurs within the university' without a strong strategic guidance from their home organisations. Failure to win external funding would have a drastic effect for 
individual researchers: "you get sacked when there is no more funding. No one intervenes to our activities as long as we can generate funds". (UTU, researcher).

The importance of SF funded projects was described in very different ways: whereas the researchers thought it is 'a relief' to concentrate on the regional priorities and objectives of the project instead of traditional measurements of academic success (e.g. the performance indicators of the state funding model), the management of parent universities either worried that these projects do not advance scientific research because of their more applied approach or they were not sufficiently aware of the SF activities in detail. In general, the SF projects are not usually based on cutting-edge technology, but their function is more likely to transfer existing results, so the focus is more on capacity building of the region, which does not necessarily foster research excellence.

The management expressed their concern also on the amount of granted SF funding. SF instruments are more common in the remote units, such as university consortia, and the parent universities need to 'compensate' this by generating more external funds from sources that are applicable with universities' internal 'full cost model' - only funding from these streams can help to secure sufficient funding from the state: "If it would be the other way around, things would go financially wrong" (TUT, management). The management also considered the amount of available SF funding to be too small so that it would be truly attractive for universities: "We aim to win long-term funding and bigger amounts" (TUT, management). On the contrary, the researchers working with SF projects stated rather bluntly, that SF funding is crucial for engagement activities: "If we want to do regional development, we need ERDF funding" (TUT, researcher). However, 


\section{The university third mission and the European Structural Funds in peripheral regions \\ Insights from Finland}

most interviewees largely believed SF projects to be a potential means to deliver third stream activities in practice:

"SF funding gives possibility to truly implement projects that are aimed for societal impact in universities: It allows us to concentrate more on the actual content of the projects rather than on academic results that measure 'success'." (Aalto, researcher).

The lack of internal coordination of project portfolio on the UC-Pori might lead to situations where different units of the UC-Pori compete with themselves for SF funds. This was not seen as a problem, because "it is the funding authority's task to choose which bids are granted funding" (TUT, researcher), and UC-Pori has strived to tighten internal collaboration in the recent years. Few of the interviewees emphasised, that SF projects should be taken into account when designing longterm research agendas, and there should be more critical discussion on role of the SF projects within the universities:

"I agree that also here in remote campus we should have other sources of funding, so in that sense it is important to think how SF projects fits in the unit's strategy. We cannot build all our activities on SF funding, but the decision-making authority should be here (in Pori, not in the main campus)." (TUT, researcher)

Some of the challenges were linked to internal logic of the instruments, which typically are not very agile and the guidelines being even counter-effective in relation to the desired effect, especially in supporting SMEs. However, the researchers felt that:

"--it is not just about the (SF) instrument, it is also about the internal chain. To be frank, they have wanted us to be more part of the main campus, and not a separate unit. I guess it is the same thing with all the units of UC-Pori." (TUT, researcher). 
The centralised coordination was indeed mentioned as one of the issues that complicates implementation of the SF projects, but the researchers were still highly motivated to apply for these funds, though if these remote units "fail to sell the idea (of regional engagement activities) to their parent organisation, they will stay on a very small scale" (TUT, researcher).

\subsection{SF Project outputs}

Though the UC-Pori units' parent universities have little interest in engaging in SF activities, the local researchers had increasingly thought about maximising the benefits from such activities, especially finding ways to combine regional engagement activities with other core functions: "We think about these links for every projects, I think there has to be a synergy there." (TUT, researcher). All researchers had faced expectations to deliver more academic outputs: "Everybody that calls her/himself a researcher has to publish" (UTU, researcher), though it is increasingly challenging in SF projects because of their strict timeframes and guidelines that do not allow allocating time for basic research work. In many cases they can result in conference papers and provide rich data sets for further research, but SF activities can also facilitate achieving individual researcher's and research group's goals:

\footnotetext{
"In our team we require two publications per year; it is possible to link these three (missions)" (TUT, researcher)

"We require that all our project researchers are PhD students. PhD students that work in SF projects make more progress that those who teach." (TUT, researcher)
}

As discussed earlier, the strong collaboration element of SF funded projects was seen as a two-way street: "—we get (knowledge) from the firms and they get from 
us" (TUT, researcher), though there is a limited number of potential partners in the region and businesses have not exploited SF funding and project's results as much as they could have - partly because of the strict limitations of SF instruments. However, the collaboration has brought people together and some researchers have ended up working in the local firms. In addition, SF projects can be seen as 'seed money', so that they generate academic results more indirectly: "They (SF projects) enable small-scale pilots and publishing preliminary results, which makes it easier to apply for larger projects in the same area." (UC-Pori, management).

The longer the researchers had been working with SF projects, the clearer they described the change after the renewed University Act (558/2009), which led to performance-based state funding. After the reform, the universities have become more focused on traditional academic outputs, which has made SF funding even more problematic. The interviewees with less experience did not recognize other research funding instruments being more desirable, while the senior staff members had received a clear signal from their home universities to focus on other calls. The more senior researchers were generally concerned about the rise of managerialism in the university: after the new state funding model, the researchers implementing SF projects have become forced to work on "some sort of publications on the side" (UTU, researcher).

\section{Discussion: Academic core and SF activities}

In this section, the findings from the case of UC-Pori are further discussed in order to identify specific characteristics of university-led SF activities in relation to four overlapping key challenges derived from literature; collaboration, university 
organisational culture, SF administrative procedures and SF project outputs. The impact of these challenges to characteristics of university-led SF-projects are finally summarised in Table 2.

\subsection{Characteristics of university-led SF projects}

In the case of UC-Pori, the SF funding have helped universities to initiate longer term collaboration with HEIs and other stakeholders, though the universityindustry cooperation is less established in the region of Satakunta and there is a lack of potential business partners. The collaboration through SF projects allows individual researchers and research groups to increase their skills base. It also contributes to knowledge transfer activities and general capacity building of the region as the university-led SF projects are largely based on local priority sectors. Working with public sector stakeholders in different stages of policy processes can have an effect to local policy processes, in particular through RIS3 formulation.

UC-Pori carries out different types of SF activities, which typically have a strong networking element. Whereas some SF projects engage with a variety of local stakeholders, many are more targeted to business partners. In both cases, the dissemination activities are important, as they "provide a possibility for the firms to exploit developed tools" (UC-Pori, management), though also sharing results is more complicated in a rural region with less tradition to work with companies.

UC-Pori's regional role is to strengthen the regional skills level, offer local access to higher education and attract students from other parts of the country. The researchers working at the Pori campus and the top management of parent universities brought up the important regional role of UC-Pori referring largely to the third mission. The local researchers also saw added value in bringing university 


\section{The university third mission and the European Structural Funds in peripheral regions \\ Insights from Finland}

activities to a heavily industry-based region with little academic traditions, which can be reinforced through SF activities, especially in the establishment phase of the UC-Pori units:

"SF funding has enabled local university activities that would not have been possible otherwise. The region of Satakunta wants us here, because we provide access to higher education and research, whatever kind it would be, because it brings knowhow to the area." (UTU, researcher).

Over the past decade, some UC-Pori units have managed to build their research agendas systematically on SF funded projects from practise to theory, "creating social innovations with practical orientation" (TUT, researcher) despite the limitations of SF funding instrument - such as heavy administrative procedures, unsuitable output indicators and high match funding rates - and the lack of internal coordination and strategic management within parent universities. The SF projects can provide a channel for academics to get in touch with different target groups, but they also indirectly contribute to generating research outputs: "They can provide a rich empiric data and show how the real life works; collaboration with different stakeholders provides two-way social communication." (UTU, researcher). The SF activities can thus facilitate obtaining PhD degrees and generate conference papers, despite the purely networking-based activities, that do not typically lead to any kind of academic outputs.

Responding to regional needs through SF projects was partly seen as having a negative impact on research excellence, especially by the management of the parent universities: "Regional research is a delusion, there is no such thing. Of course, the research has to generate benefit for the local area, but the results have to be transferable also outside of the Satakunta region" (UC-Pori, management). 
The SF projects also typically lack an international aspect. Therefore, it is not an easy task to design and implement SF projects that are both beneficial for the region and create academic outputs. Currently, the focus of university-led SF projects tends to be on the former:

"SF project have an applied research approach, which is contradictory when compared to other university's activities." (Aalto, researcher)

"Universities do not want to participate to SF projects. They are unprofitable, and it is hard to cover the match-financing and they do not serve the two core missions." (UTU, researcher)

Because of this mismatch the researchers at the Pori campus felt that they are forced to balance between the differing views of their local partners and their home universities: "The biggest challenge is to find balance between universities" increasingly results-based approach and this regional development mission, like we have here in Porl' (TUT, researcher)." In the best-case scenario, typically when SF collaboration was based on long-term partnerships and strategically planned as part of research group's agenda, different missions come together naturally. Then the SF activities can have clear links with research and knowledge transfer activities:

"I think that this kind of project work allows us to do both academic research and transfer knowledge to business sector. In addition to business collaboration, regional development and more practical work we conduct academic research on the side." (UTU, researcher) 
Table 2. The impact of current challenges in university-led SF projects in the case of UC-Pori

\begin{tabular}{|c|c|c|c|}
\hline Challenge & Impact & Observed key elements & Impact \\
\hline Collaboration & $\begin{array}{l}\text { Create non- } \\
\text { desirable } \\
\text { competition; } \\
\text { Lack of regional } \\
\text { coordination; } \\
\text { Lack of business } \\
\text { partners } \\
\text { (peripheral } \\
\text { regions). } \\
\end{array}$ & $\begin{array}{l}\text { Contribute to creating } \\
\text { long-term collaboration } \\
\text { with other HEIs, } \\
\text { businesses and public } \\
\text { organisations; more } \\
\text { complicated in remote } \\
\text { regions with less } \\
\text { potential partners. }\end{array}$ & $\begin{array}{l}\text { Facilitate knowledge transfer } \\
\text { and capacity building; } \\
\text { Foster creating a culture of } \\
\text { collaboration with academia } \\
\text { and regional stakeholders; } \\
\text { May have an impact on policy- } \\
\text { making. }\end{array}$ \\
\hline $\begin{array}{l}S F \\
\text { administrative } \\
\text { procedures }\end{array}$ & $\begin{array}{l}\text { High bureaucracy; } \\
\text { High risk form of } \\
\text { funding; } \\
\text { High match- } \\
\text { funding rates; } \\
\text { Difficulties in } \\
\text { cross-regional } \\
\text { collaboration. }\end{array}$ & $\begin{array}{l}\text { Do not fund basic } \\
\text { research or degree } \\
\text { education; High success } \\
\text { rates; Regional policies } \\
\text { favour STEM; } \\
\text { Bureaucratic, non- } \\
\text { transparent and } \\
\text { complicated to manage; } \\
\text { Internal guidelines } \\
\text { complicated with } \\
\text { business collaboration. }\end{array}$ & $\begin{array}{l}\text { Unclear guidelines may lead to } \\
\text { clawbacks and accessibility to } \\
\text { opportunistic behaviour; } \\
\text { Lower quality of implemented } \\
\text { projects; forces to build } \\
\text { research agendas too much on } \\
\text { local needs; } \\
\text { Unused potential in supporting } \\
\text { entrepreneurial activities. }\end{array}$ \\
\hline $\begin{array}{l}\text { University } \\
\text { organisational } \\
\text { culture }\end{array}$ & $\begin{array}{l}\text { Embedding } \\
\text { projects to } \\
\text { academic core } \\
\text { complicated; } \\
\text { Lack of financial } \\
\text { resources for } \\
\text { match-funding; } \\
\text { Lack of internal } \\
\text { coordination; } \\
\text { Lack of academic } \\
\text { outputs. }\end{array}$ & $\begin{array}{l}\text { Enable finding new ways } \\
\text { to work in regard to } \\
\text { basic mission; } \\
\text { Lack of strategic } \\
\text { planning and top } \\
\text { management's } \\
\text { involvement with } \\
\text { regional engagement } \\
\text { activities; } \\
\text { Focus widely on } \\
\text { generating traditional } \\
\text { academic outputs. }\end{array}$ & $\begin{array}{l}\text { Important source of funding in } \\
\text { delivering third stream } \\
\text { activities; } \\
\text { Forces individual researchers } \\
\text { to work as 'entrepreneurs'; } \\
\text { Less attractive funding source } \\
\text { for universities in regards to } \\
\text { state funding model; } \\
\text { Forces academics to } \\
\text { camouflage research activities. }\end{array}$ \\
\hline $\begin{array}{l}\text { SF Project } \\
\text { outputs }\end{array}$ & $\begin{array}{l}\text { Over-estimated } \\
\text { outputs; } \\
\text { Lack of academic } \\
\text { outputs; } \\
\text { Low number of } \\
\text { commercial } \\
\text { results. }\end{array}$ & $\begin{array}{l}\text { Applied approach; } \\
\text { Allow researchers to } \\
\text { 'work in the field'; } \\
\text { Enable small-scale } \\
\text { regional pilots. }\end{array}$ & $\begin{array}{l}\text { Projects based on transferring } \\
\text { existing results instead of } \\
\text { cutting-edge technology; } \\
\text { Offers rich data sets for further } \\
\text { research; Publishing initial } \\
\text { results can be 'stepping stones } \\
\text { to large-scale research } \\
\text { projects. }\end{array}$ \\
\hline
\end{tabular}




\section{The university third mission and the European Structural Funds in peripheral regions \\ Insights from Finland}

\subsection{Managing of regional engagement activities in entrepreneurial universities}

The case of the UC-Pori tells a story of four Finnish universities, whose remote units located in more peripheral area are forced to juggle between regional engagement activities and delivering traditional academic outputs. The Structural Funds programmes are one of the tools to support the former, though the national guidelines of the instruments are not suitable for directly generating the latter. This has forced researchers to 'camouflage' research outputs from these development projects or to work on publications or PhD degrees 'on the side' of SF activities. This is partly due to the rise of managerialism and other recent changes in the higher education policies in Finland. Especially the performance-based indicators in the state funding model has steered universities to focus more on the generation of academic outputs such as degrees and peer-reviewed publications.

The top management of the four home organisations emphasised, that the lack of suitable indicators for the engagement activities in the current state funding model forces them to measure success solely with publications and degrees: "The state is the most important source of funding, so it easily leads us to follow their indicators" (TUT, management). Even though national HE policies and many of the key funding instruments, e.g. the Academy of Finland, underline the importance of societal impact of university activities, the overall absence of proper indicators and difficulties to gain access to information (e.g. collaboration projects with firms may be classified) makes the issue very complicated.

"SF has their own aims, and maybe university tries to combine those to its own objectives, but they do not go hand in hand. Universities don't have a need for the regional engagement, -- it cannot be measured and it is unimportant in the funding model. (UTU, researcher). 
However, the interviewed management would rather not change the current indicators than to replace them with too constricted ones: "In the worst case scenario we just end up counting patents. And that is a very narrow way to measure impact" (TUT, management). Some pointed out, that external research funding and publications are suitable also for measuring impact, though as an exception, University of Turku was currently working on internal performance indicators for societal impact, in which the amount of granted SF funding was one of the measurements of success. Overall the case of UC-Pori demonstrates how national and regional policies determine the conditions in which universities can transform towards entrepreneurial organisations (Stensaker \& Benner, 2013), also what kind of funding is available for these activities (Trippl et al., 2015).

SF funding was considered to be complicated also in relation to universities' internal mechanisms, though the researchers pointed out that these are organisational issues that could be resolved with a support of university management. In the case of UC-Pori, it seems that a diversified funding base is not necessarily a step towards an entrepreneurial university or obtaining institutional autonomy (Gibb \& Hannon, 2006; Armbruster, 2008) unless universities learn how to deal with these internal issues. Currently, the SF project were not seen as profitable even when the match-funding was covered by a third party. Although universities' third mission is mainly formalised in regional policies and R\&D funding schemes (Vorley \& Nelles, 2009; Nelles \& Vorley, 2010), the implementation of these incentives remains very complex, and as noted by D'Este and Perkmann (2011), it is obvious that monetary incentives alone are not sufficient for initiating successful university-industry collaboration unless mission support one another (Etzkowitz \& Kloften, 2005; Etzkowitz, 2013). 
In the case of UC-Pori, the lack of strategic planning of regional engagement activities was repeatedly emphasised. The burden to find ways to combine all the three missions falls mostly on the shoulders of individual researchers, though it is evident that "the regional needs and the core mission do not always meet" (UTU, researcher). This implies that UC-Pori and its parent universities have not managed to design a successful strategy for managing the third mission that would take individual, disciplinary and institutional issues into account (Pinheiro et al., 2015). In particular, the researchers specialised in non-STEM fields hoped, that the overall comprehension and discourse on science in HE policies would go beyond publications and rankings, focusing more on open science and universities' regional impact, in which SF programmes were seen as a very important source of funding.

The fact that researchers have managed to win larger project funding from the SF without any 'payback' from the state funding model can cause frustration among the academic staff and demotivate them to apply for the SF funding. Overall, the parent universities' management suggested that SF funding and other applied science projects fits better with universities of applied Sciences. Universities' third mission was considered to be delivered indirectly through education and research, also in university consortia, which supposedly have an enhanced regional mission. In reality, combining all three mission remain very challenging (Chatterton \& Goddard, 2009). From the management's point of view, the consortia are even more complicated, because these remote units are built on a regional will and commitment to local higher education and there is a strong political push with earmarked state funding, so their (research) activities redeem more reactive than strategic. 
As Clark (1998) noted, responding to regional needs is complicated in a traditional academic infrastructure, but it remains challenging also in a network of universities with a specific regional mission: the lack of clear common research agenda (FINHEEC, 2013) and overlapping - and sometimes contradictory needs - of different stakeholders and parent universities makes regional activities very complicated to plan and deliver. Finally, the data collected from UC-Pori reveals that Finnish universities mainly continue to run these remote units in peripheral regions, because they generate more state funding through degrees. Thus, their existence is linked to the financial conditions, including external resources from the municipalities and SF funding, which demonstrates how universities are more inclined to go for opportunistic rather than strategically entrepreneurial behaviour (Stensaker \& Benner, 2013).

\section{Conclusion: Academic core and reglonal development - Managing universities' third mission through Structural Funds programmes}

This study sought to contribute to the current discussion on universities' third mission and entrepreneurial universities through examining how European Cohesion Policy transformed into national SF Operational Programmes can enhance universities' regional engagement. Through a single case study of the University Consortium of Pori, the aim was to explore how universities can manage and deliver their third mission through SF programmes and to investigate the specific characteristic of SF activities conducted by universities. The tentative findings from UC-Pori's engagement with SF programmes are supported by previous studies: SF projects can indeed strengthen universities regional engagement (Charles \& Michie, 2013) and their R\&D capacity (Muizniece \& 
Peiseniece, 2012), but the implementation of SF projects within a Finnish university framework remains challenging because of a number of organisational issues, higher education policies that focus solely on traditional academic outputs and finally, strict guidelines of SF funding.

SF programmes may enable universities to respond to regional needs through collaborative research projects (Fonseca \& Salomaa, 2019), but the administrative burden of the Operational Programmes (Spilanis et al., 2016) hinders obtaining the potential of these activities, which was evident in the case of UC-Pori. This pushes beneficiaries towards alternative national funding in more innovative initiatives (Bachtler \& Wishlade, 2004), though in the case of Pori, this is also due to the fact that the Finnish state funding model steers universities towards traditional academic outputs, which are not automatically - or easily - aligned with SF projects' deliverables. Another big mismatch detected from the interview data was UC-Pori's strong orientation towards regional engagement; whereas UC-Pori's personnel found that SF instruments are one of the key tools in delivering their regional mission, their parent universities' top management regarded such activities as irrelevant, even though SF projects could support further development of key disciplines and even contribute to planning and implementation of new study programmes.

However, through an enhanced strategic planning (Muizniece \& Peiseniece, 2012), more active engagement of the university management and carefully planned project portfolio, universities could strengthen their regional engagement activities through SF projects (Charles \& Michie, 2013) instead of the current, rather ad-hoc approach based on individual academics' effort to support their regions and generate external funding - and to safeguard their jobs. In doing so, the 
universities could set and achieve more realistic entrepreneurial goals assigned in regional development policies, such as supporting local SMEs, networking and knowledge transfer in peripheral areas (Brown, 2016) through SF activities.

Previous studies emphasise, that universities' third mission is heavily shaped by their regional context (Salomaa, 2019); As also the formulation and implementation of SF Operational Programmes are nationally differentiated and very dependent on regional circumstances (Bachtler \& Wren, 2007), further comparative studies on entrepreneurial universities' engagement with SF projects could provide more insight on the ways their third stream activities are delivered on a micro scale (Lebeau \& Cochrane, 2015). Further evidence could facilitate designing institutional strategies for managing the third mission more efficiently so that each mission enhances one another (Etzkowitz \& Kloften, 2005; Etzkowitz, 2013), taking different individual, disciplinary and institutional issues into account (Pinheiro et al., 2015). This would also enable maximising the regional benefits of university-led SF activities.

\section{References}

Agrawal, A. (2001). University-to-Industry knowledge transfer: literature review and unanswered questions. International Journal of Management Reviews, 3, 285-302.

Arbo, P. \& Benneworth, P. (2007). Understanding the Regional Contribution of Higher Education Institutions: A Literature Review, OECD Education Working Papers 9, OECD Publishing, Paris.

Armbruster, C. (2008). Research Universities: autonomy and self-reliance after the Entrepreneurial University. Policy Futures in Education, 6, 372-389.

Autonomous Robot Ecosystem, website https://www.tuni.fi/en/research/autonomous-robot-ecosystem, accessed $2^{\text {nd }}$ August 2019.

Bachtler, J. \& Wishlade, F. (2014). Searching for Consensus: The Debate on Reforming EU 
Cohesion Policy. European Policies Research Paper 55, European Policies Research Centre.

Bachtler, J. \& Wren, C. (2006). Evaluation of European Union Cohesion policy: Research questions and policy challenges. Regional Studies, 40:2, 143-153.

Benneworth, P. \& Sanderson, A. (2009). The regional engagement of universities: Building capacity in a sparse innovation environment. Higher Education Management and Policy, 21:1, 123-140.

Benneworth, P. \& Cunha, J. (2015). Universities' contributions to social innovation: reflections in theory \& practice. European Journal of Innovation Managemen,18, 508-527.

Breznitz, M.S. \& Feldman, M.P. (2012). The engaged university. Journal of Technology Transfer, 37, 139-157.

Brown, R. (2016). Mission impossible? Entrepreneurial universities and peripheral regional innovation systems. Industry and Innovation, 23:2, 189-205.

Campusbased competence building for social welfare and healthcare services, website https://sites.tuni.fi/kampussote/in-english/, accessed $2^{\text {nd }}$ August 2019.

Charles, D. (2016). The rural university campus and support for rural innovation. Science and Public Policy, 43:6, 763-773.

Charles, D. \& Michie, R. (2013). Evaluation of the main achievements of cohesion policy programmes and projects over the longer them in 15 selected regions. Case Study North East England.

Charles, D., Kitagawa, F. and Uyarra, E. (2014). University in Crisis? - new challenges and strategies in two English city-regions. Cambridge Journal of Regions, Economy and Society, 7:2, 475-496.

Chatterton, P. \& Goddard, J. (2000). The Response of Higher Education Institutions to Regional Needs. European Journal of Education, 35:4, 475-496.

Clark, B.R. (1998). Entrepreneurial Universities. Organizational Pathways of Transformation, IAU Press.

Clark, B.R. (2004). Delineating the character of the entrepreneurial university. Higher Education Policy, 17, 355-370.

DELTA Research database, http://delta.ucpori.fi/?lang=en, first accessed $30^{\text {th }}$ of August 2017. 
D'Este, P., \& Perkmann, M. (2011). Why do academics engage with industry? The entrepreneurial university and individual motivations. The Journal of Technology Transfer, 36:3, 316-339.

Etzkowitz, H. (2013): Anatomy of the entrepreneurial university, Social Science Information, $52: 3,486-511$.

Etzkowitz, H. \& Kloften, M. (2005). The innovating region: toward a theory of knowledgebased regional development. R\&D Management, 35:3, 243-255.

European Commission (2010): EUROPE 2020. A European strategy for smart, sustainable and inclusive growth. Retrieved from http://ec.europa.eu/eu2020/pdf/COMPLET\%20EN\%20BARROSO\%20\%20\%20007\%20\%20Europe\%202020\%20-\%20EN\%20version.pdf

European Commission, Cohesion Policy website https://ec.europa.eu/regional policy/en/policy/how/priorities/, accessed 1 ${ }^{\text {st }}$ August 2019.

European Regional Development Fund and on specific provisions concerning the Investment for growth and jobs goal and repealing, Regulation (EC) No 1080/2006.

Retrieved from https://eur-lex.europa.eu/legal-content/EN/TXT/PDF/?uri=CELEX:32013R1301\&from=EN,

Finnish Ministry of Culture and Education (2017). Universities core funding model. Retrieved from https://minedu.fi/documents/1410845/4392480/Universities funding 2017.pdf/abc0974d -b8d5-4486-a12a-aa141d54b66f/Universities funding 2017.pdf

Finnish Ministry of Education and Culture, MoEC (2015): Vastuullinen ja vaikuttava. Tulokulmia korkeakoulujen yhteiskunnalliseen vaikuttavuuteen, 2015:13. Retrieved from http://julkaisut.valtioneuvosto.fi/bitstream/handle/10024/75117/okm13.pdf

Flyvbjerg, B. (2006). Five Misunderstandings about Case-Study Research. Qualitative Inquiry,12:2, 219-245.

Fonseca, L. \& Salomaa, M. (2019)._Entrepreneurial universities and regional innovation: matching smart specialisation strategies to regional needs? RUNIN Working paper series, 03/2019.

Foray, D., David, P. A., \& Hall, B. H. (2011). Smart Specialisation from Academic Idea to Political Instrument, the Surprising Career of a Concept and the Difficulties Involved in its Implementation. Retrieved from https://infoscience.epfl.ch/record/170252

Fratesi, U. \& Wishlade, F. G. (2017). The impact of European Cohesion Policy in different contexts. Regional Studies, 50:6, 817-821. 
Gagliardi, L. \& Percoco, M. (2017). The impact of European Cohesion Policy in urban and rural regions. Regional Studies, 51:6, 857-868.

Gibb, B. \& Hannon, P. (2006). Towards the Entrepreneurial University? International Journal of Entrepreneurship Education, 4, 73-110.

Jongbloed, B., Enders, J. \& Salerno, C. (2008). Higher education and its communities: Interconnections, interdependencies and a research agenda. Higher Education, 56, 303324.

Lebeau, Y. \& Cochrane, A. (2015). Rethinking the 'third mission': UK universities and regional engagement in challenging times. European Journal of Higher Education, 5:3, 250-263.

McCann, P., \& Ortega-Argilés, R. (2015). Smart Specialization, Regional Growth and Applications to European Union Cohesion Policy. Regional Studies, 49:8, 1291-1302.

Miles, M. B., Huberman, M. A. \& Saldana, J. (2014). Qualitative Data Analysis. A Methods Sourcebook, SAGE Publications, US.

Muizniece, L. \& Peiseniece, L. (2012). EU Structural Funds Investment in R\&D and its influence on innovation development - the case of university of Latvia. in European Integration Studies, 6 .

Nelles, J. \& Vorley, T. (2010). From Policy to Practice: engaging and embedding the third mission in contemporary universities. International Journal of Sociology and Social Policy, 30:7, 341-353.

Percoco, M. (2017): Impact of European Cohesion Policy on regional growth: does local economic structure matter? Regional Studies, 51:6, 833-843.

Pinheiro, R., Langa, P. V. \& Pausits, A. (2015). The institutionalization of universities' third mission: introduction to the special issue. European Journal of Higher Education, 5:3, 227232.

Regional Council of Satakunta, website

http://www.satakuntaliitto.fi/english, accessed 12th November 2018.

Regional strategic plan of the Satakunta region 2018-2021. Retrieved from http://www.satakuntaliitto.fi/sites/satakuntaliitto.fi/files/tiedostot/Aluekehitys/MAKO 201 8 2021/Satakunnan maakuntaohjelma 2018-2021 SahkoinenJulkaisu LowRes.pdf

Rodriguez-Pose A. \& Fratesi, U. (2004). Between Development and Social Policies: The impact of European Structural Funds in Objective 1 regions. Regional Studies, 38:1, 97113. 
Roper, C.D. \& Hirth, M. A. (2005). A History of Change in the Third Mission of Higher Education: The Evolution of One-way Service to Interactive Engagement. Journal of Higher Education Outreach and Engagement,10:3, 3-20.

Santos, D., \& Caseiro, N. (2015). The Challenges of Smart Specialization Strategies and the Role of Entrepreneurial Universities: A New Competitive Paradigm. In Carmo Farinha, L. M., Ferreira, J. J. M., Smith, H. L. \& Bagchi Sen, S. (Eds.), Handbook of Research on Global Competitive Advantage through Innovation and Entrepreneurship.

Salomaa, M (2019). Third mission and regional context: assessing universities' entrepreneurial architecture in rural regions- Regional Studies, Regional Science, 6:1, 233249.

Satakunta Region: RIS3 strategy (2014). Retrieved from http://www.satakuntaliitto.fi/sites/satakuntaliitto.fi/files/RIS3 Satakunta2014 TEM.pdf

Saunders, M., Lewis, P. \& Thornhill, A. (2016). Research Methods for Business Students (7th edn.), Pearson.

Spilanis, I., Kizos, T., \& Giordano, B. (2016). The effectiveness of European Regional Development Fund projects in Greece: Views from planners, management staff and beneficiaries. European Urban and Regional Studies, 23:2, 182-197.

Statistics Finland. Retrieved from

https://www.tilastokeskus.fi/tup/suoluk/suoluk vaesto en.htm|\#demographicdependenc yratiobymunicipality, 2017

Stensaker, B. \& Benner, M. (2013). Doomed to be Entrepreneurial: Institutional Transformation of Institutional Lock-Ins of 'New' Universities?. Minerva, 51:4, 399-416.

Structural Fund information service: ERDF and ESD projects in Finland during the 20142020 programme period, https://www.eura2014.fi/rrtiepa/?lang=en, first accessed on the $1^{\text {st }}$ of September 2017.

Sustainable growth and jobs 2014 - 2020 - Finland's structural funds programme. Retrieved from https://www.rakennerahastot.fi/documents/10179/43217/Ohjelmaasiakirja+valmis.pdf/

Tampere university, website https://www.tuni.fi/en/about-us, accessed 20 $0^{\text {th }}$ February 2019.

The Finnish Higher Education Evaluation Council, FINHEEC (2013). Korkeakoulut yhteiskunnan kehittäjinä. Korkeakoulujen yhteiskunnallisen ja alueellisen vaikuttavuuden 
arviointiryhmän loppuraportti, 5:2013. Retrieved from

https://karvi.fi/app/uploads/2014/09/KKA 0513.pdf

Trippl, M, Sinozic, T. \& Lawton Smith, H. (2015). The Role of Universities in Regional Development: Conceptual Models and Policy Institutions in the UK, Sweden and Austria. European Planning Studies, 23:9, 1722-1740

Universities Act 558/2009. Retrieved from http://www.finlex.fi/en/laki/kaannokset/2009/en20090558

Uyarra, E. (2010). Conceptualizing the Regional Roles of Universities, Implications and Contradictions. European Planning Studies, 18:8, 1227-1246.

Vorley, T. \& Nelles, J. (2009). Building Entrepreneurial Architectures: a conceptual interpretation of the Third Mission. Policy Futures in Education, 7:3, 284-296.

Zomer, A. \& Benneworth, P. (2011). The Rise of the University's Third Mission. In Enders, J., de Boer H.F. \& Westerheijden, D.F. (Eds.), Reform of Higher Education in Europe (pp. 81102). Sense Publishers. 